\title{
Z lotu ptaka. „Relief Praszwajcarii” Franza Ludwiga Pfyffera oraz inne modele terenu jako media naukowego zawłaszczania Alp w późnym XVIII wieku*
}

\author{
https://doi.org/10.19195/2084-4107.14.5
}

Do stawiających najwyższe wyzwania form zawłaszczania gór w XVIII wieku zalicza się z całą słusznością działalność topograficzną. Stworzenie dokładnej mapy tak kompleksowego krajobrazu było bowiem zadaniem stawiającym wymagania odnośnie do zarówno techniki pomiaru, jak i obrazowania. Do spełnienia tych wymagań konieczne było przede wszystkim skonstruowanie narzędzi tudzież wynalezienie technik graficznych. Proces ten — określony mianem ,digitalizacja” — do dziś nie jest zamknięty, można jednak przyjąć, że w XVIII wieku stare techniki pomiarowe zostały już udoskonalone, nowe zaś były wypróbowywane, tworząc warunki do tworzenia map, które potem, w XIX wieku, posłużyły za ważny element tworzenia narodowej tożsamości młodych państw europejskich ${ }^{1}$. W tym sensie postępy osiemnastowiecznej kartografii można określić jako punkt zwrotny.

Wiążącym przedstawieniem topograficznym dla Szwajcarii była aż do XIX wieku, powstała w roku 1712 i wielokrotnie wznawiana, Nova Helvetiae tabula geographica — mapa w czterech arkuszach autorstwa pochodzącego z Zurychu uczonego Johanna Jakoba Scheuchzera (1672-1733). Zawierała ona jednakowoż wiele wad spowodowanych właśnie uwarunkowaniami związanymi z techniką pomiarów i obrazowania, które Scheuchzer napotkał, ale i warunkowanych jego sposobem pracy mającym niewiele wspólnego ze metodami pracy późniejszych kartografów i inżynierów wykonujących pomiary².

* Niniejszy artykuł opiera się na długoletnim projekcie badawczym finansowanym przez Szwajcarski Narodowy Fundusz Wspierania Badań Naukowych. Wyniki zostały opublikowane w A. Bürgi, Relief der Urschweiz. Entstehung und Bedeutung des Landschaftsmodells von Franz Ludwig Pfyffer, Zürich 2007.

1 D. Gugerli, D. Speich, Topografien der Nation. Politik, kartografische Ordnung und Landschaft im 19. Jahrhundert, Zürich 2002.

2 ,»Mapa Scheuzera« była pierwszą mapą Konfederacji o największej dotąd skali i dokładności złożoną z wielu arkuszy, ale jednolicie uformowaną. Jednocześnie znaczyła ona koniec epoki tzw. kartografii gabinetowej, w której nowe mapy tworzone były nie na podstawie szeroko zakrojonych nowych pomiarów, lecz poprzez poprawianie starych map. Mimo swoich licznych, dostrzeganych już przez sobie współczesnych, braków przedstawiała sobą imponujące osiągnięcie kulturowo-historyczne i aż do ukazania się Atlas Suisse (1786-1802) Johanna Heinricha Weissa i Johanna Rudolfa Meyera stanowiła główną mapę Szwajcarii XVIII wieku" - J.J. Scheuchzer an Johann I Bernoulli, 1710.07.19, przyp. 3 (Martin Rickenbacher), Bazylejska edycja korespondencji Bernoullego, https:// ub.unibas.ch/bernoulli/index.php/1710-07-19_Scheuchzer_Johann_Jakob_Bernoulli_Johann_I (dostęp: 30.04.2020); por. M. Cavelti Hammer, An Kunstwerken lernen, zum Beispiel: Die Schweizerkarte von Johann Jakob Scheuchzer um 1720, „Cartographica Helvetica” 1, 1990, s. 29-31.

Góry — Literatura - Kultura 14, 2020

(C) for this edition by CNS 
Najbardziej zaawansowane produkty kartograficzne tworzono w tamtych czasach we Francji ${ }^{3}$. Od 1731 roku francuskim wojskom przydzielani byli w polu ingénieurs géographes, mający za zadanie kartować okupowane kraje. W czasie wojny o sukcesję hiszpańską zaczęto systematyczne ujmowanie, będącej w czasach Ludwika XIV i jego następcy przedmiotem ciągłych walk, południowej granicy państwa. W 1733 roku, z początkiem wojny o sukcesję polską, jako pierwszy znaczący rezultat tych starań ukazała się na piętnastu arkuszach mapa z granicami między Francją a Flandrią i Niemcami. Uchodziła za bardzo dobrą.

$\mathrm{Z}$ początku ingénieurs géographes nie pracowali jeszcze zgodnie $\mathrm{z}$ obowiązującymi naukowymi zasadami. Szybko jednak ustalono organizację i nadano jej strukturę. W 1719 roku na nadzorcę procesu wyznaczono pułkownika. Jego zadaniem było wypracować i wprowadzić stałe zasady i jednolite metody ujęć topograficznych. Dziesięć lat później directeur był brygadierem podległym bezpośrednio ministrowi wojny i dowodził dwunastoma ingénieurs géographes w randze podporuczników piechoty. Niektórzy z nich, w latach 1733-1735 przydzieleni do Armii Renu, przywieźli z tej kampanii liczne ujęcia kartograficzne. Z kolei w czasie austriackiej wojny sukcesyjnej (1741-1748) wielu ingénieurs géographes zajmowało się już ujęciami topografii. Z początku tylko triangulowano. W tym celu sięgnięto po géodésiens ou trigonomètres i zastosowano metody wypróbowane w czasie pomiarów we Flandrii przez słynnego geodetę i kartografa Césara-François Cassiniego de Thury (1714-1784), twórcę nazwanej od niego mapy Francji. Praca wojskowych specjalistów od pomiarów w krótkim czasie została sprofesjonalizowana, a jej jakość i zakres znacznie się powiększyły, tak że i oni sami zyskali na znaczeniu w armii, szczególnie po połączeniu ich z Dépôt des Fortifications. Do pomiarów używali takich samych instrumentów jak ich cywilni koledzy, a w ich bibliotekach stały po części te same dzieła, na przykład sztandarowe dzieło Nicolasa Biona Traité de la construction et des principaux usages des instruments de mathématiques, które ukazało się w 1709 roku, a potem było wielokrotnie wznawiane, czy też książki matematyka Jacques’a Ozanama ${ }^{4}$.

${ }^{3}$ H.M.A. Berthaut, Les ingénieurs géographes militaires 1624-1831, t. 1, Paris 1902; A. Blanchard, Les Ingénieurs du «Roy» de Louis XIV à Louis XVI. Etude du Corps des Fortifications, Montpellier 1979; Histoire militaire de la France, red. A. Corvisier, t. 1, Paris 1992, s. 470-483; t. 2, Paris 1994, s. 129-149; M. Kirschbaum, Die Mémoires/Dossiers der französischen Ingénieurs géographes militaires des 18. Jahrhunderts zwischen Maas, Mosel und Rhein. Neue Quellen zu einem alten europäischen Kernraum, „Militärgeschichtliche Mitteilungen” 57, 1998, s. 509-518. Odnośnie do mapy Cassiniego por. M. Pelletier, La carte de Cassini. L'extraordinaire aventure de la carte de France, Paris 1990; eadem, Les cartes des Cassini. La science au service de l'Etat et des régions, Paris 2002.

${ }^{4}$ N. Bion, Traité de la construction et des principaux usages des instruments de mathématique [...], Paris 1709; J. Ozanam, Méthode facile pour arpenter et mesurer toutes sortes de superficie et pour toiser exactement la maçonnerie etc., Paris 1725; idem, Méthode de lever les plans et les cartes de terre et de mer avec toutes sortes d'instrumens et sans instrumens, la description et l'usage de ces instrumens [...] et la manière de faire les remarques des marées, courants, écueils, etc., de lever les plans des villes ennemies; Paris 1693.

Góry - Literatura - Kultura 14, 2020

(C) for this edition by CNS 
Te najlepsze pod względem pomiaru mapy z początku dysponowały jednak ograniczonymi możliwościami obrazowania. Zaznaczania wysokości za pomocą tak zwanych poziomic, jak czyniono w wieku XIX, francuskie mapy nie znały. Jedyną możliwością trójwymiarowego przedstawienia był model terenu — relief. Także tutaj Francja wiodła prym. U podstaw zbioru reliefów należącego do francuskich królów stała inicjatywa słynnego budowniczego twierdz Ludwika XIV, Sébastiena Le Prestre'a, znanego lepiej jako Maréchal de Vauban. Nie tylko wybudował on dla Ludwika XIV fortece, tworząc z północnej granicy, o którą toczyły się walki, frontière de fer, lecz kazał stworzyć odpowiedni model w celu ukazania ich położenia i ułożenia w sposób jak najbardziej przejrzysty i dokładny ${ }^{5}$.

Od XV wieku zasięg artylerii znacząco się powiększył, a średniowieczne mury miejskie nie wytrzymywały już jej ataków. Budowa kompleksowej architektury umocnień z wysuniętymi fortyfikacjami, fosami i usypanymi przed nimi wzniesieniami, pochyłościami zewnętrznych wałów fortecznych, wałami i gwiaździstymi bastionami wymagała nowych sposobów planowania, które pozwoliłyby optymalnie wkomponować twierdzę w naturalne otoczenie. Do końca XVIII wieku jedynie plan przedstawiony na reliefie umożliwiał bezpośredni i szczegółowy ogląd zespołu fortyfikacji, terenu i otoczenia.

Te dwa czynniki — wysoka kompetencja w technice pomiarowej i długie doświadczenie w tworzeniu reliefów - pozwoliły na stworzenie pierwszego opartego na triangulacji modelu części Alp Szwajcarskich.

\section{Franz Ludwig Pfyffer von Wyher (1716-1802)}

Twórcą tegoż „Reliefu Praszwajcarii” był pochodzący z Lucerny generał w służbie francuskiej Franz Ludwig Pfyffer von Wyher. Jego rodzina od XVI wieku dostarczała żołnierzy królom francuskim; w XVIII wieku była to kompania w elitarnym wojsku Gwardii Szwajcarskiej, której zadaniem była ochrona rodziny królewskiej. Pfyfferowie mieli więc bezpośredni dostęp do dworskiego aparatu władzy, łącznie z królem, i potrafili ten przywilej wykorzystać, z jednej strony finansowo, $\mathrm{z}$ drugiej - w celu zapewnienia sobie władzy w Lucernie, którą to pozycję budowali od XVI wieku.

Franz Ludwig przybył do Paryża w 1726 roku w wieku dziesięciu lat, aby jako kadet rozpocząć czekającą na niego karierę militarną, mającą go zaprowadzić na szczyt rodzinnej kompanii. W ramach swojego kształcenia oficerskiego został wprowadzony do podówczas jeszcze tajnych zbiorów reliefów w Luwrze, a w czasie wojen w latach trzydziestych i czterdziestych XVIII wieku utrzymywał kontakty z ingénieurs géographes. Jego zainteresowanie pomiarami i topografią było ściśle związane z jego karierą wojskową — namiętnie zajmował się wówczas

${ }^{5}$ Francuski zbiór reliefów por. Actes du Colloque International sur les Plans-Reliefs au Passé et au Présent, red. A. Corvisier, Paris 1993; I. Warmoes, Le musée des Plans-Reliefs. Maquettes historiques de villes fortifiées, Paris 1997. 
geometrią; jak pisał w jednym z listów: „la geometrie fait aujourdhui ma passion, mais malheureusement je n'ai jamais rien appris que de moi même" ${ }^{\text {. Miał się }}$ za samouka i jako taki podjął się w czasie swoich długich urlopów spędzanych w ojczyźnie w latach czterdziestych XVIII wieku mierzenia gór w otoczeniu Lucerny i przedstawienia ich na modelu. Udowodniono, że istniał relief wznoszącej się nad Lucerną góry Pilatus, wykonany przez niego w 1750 roku, „odrysowany geometrycznie i naniesiony z podziałką"7. Niestety już nie istnieje. Informacja ta daje jednak punkt orientacyjny początku jego prac pomiarowych. Jeśli wziąć pod uwagę, że Pfyffer jako koniec swoich prac nad „Reliefem Praszwajcarii” podaje rok 1786, można powiedzieć, że poświęcił połowę swojego życia na pomiary, budowę i dopracowanie szczegółów tegoż reliefu, a więc można mówić — w sensie dosłownym — o dziele życia (zob. ilustracja 1).

„Relief Praszwajcarii” ma wielkość 6,7 × 3,9 metra, skala wynosi $1: 11$ 500, obejmuje mniej więcej jedną dziesiątą terytorium dzisiejszej Szwajcarii. Góry zostały przedstawione jako wyższe niż w rzeczywistości. Relief opiera się, jak już wspomniano, zarówno na triangulacji, jak i na barometrycznych pomiarach wysokości. Duża skala pozwala - podobnie jak w wypadku francuskich reliefów fortyfikacji - na precyzyjne ujęcie detali w przedstawieniu krajobrazu. W centrum znajduje się Jezioro Czterech Kantonów i charakterystyczne góry tej okolicy — Pilatus i Rigi. Dookoła widać centralną Szwajcarię z mniejszymi lub większymi częściami kantonów Lucerny, Unterwalden, Zug, Uri, Schwyz i Bern. Drogi są ukazane za pomocą przyczepionych sznurków, w górach zaś namalowano ścieżki. Ujęte są także wody — oprócz jezior pojawiają się rzeki i strumienie reprezentowane przez pomalowane na niebiesko skręcone struny, co ma sprawiać wrażenie, że płyną. Ukazane są też struktury siedlisk, takich jak większe miasta, wsie i przysiółki, a nawet poszczególne domy i kościoły oraz znaczące budowle: zamki, wieże strażnicze czy ważne mosty.

Dzięki temu reliefowi udało się przedstawić w skali wycinek jednej z najbardziej złożonych topografii Europy. Dokładność zmienia się w zależności od trudności terenu, wokół Lucerny model charakteryzuje się dużą dokładnością; był to rodzinny teren Pfyffera, na którym przypuszczalnie przeprowadził większość pomiarów. W Alpach rozbieżność względem oficjalnych topograficznych wartości obecnych szwajcarskich pomiarów jest znaczna ${ }^{8}$. Reasumując, można jednak stwierdzić, że „Relief Praszwajcarii” był kamieniem milowym w topograficznym przedstawianiu Szwajcarii. Po tej pracy nie było już powrotu do map z wcześniejszych czasów.

${ }^{6}$ Pfyffer an Micheli, 28. April 1761, Archives d'Etat de Genève, Arch. Micheli, Papiers JBMC, $\mathrm{n}^{\circ} 720$ bis.

7 J. Leu, Reißbeschreibungen durch die Schweitz 1722-1763, Biblioteka Centralna w Zurychu, Ms. L. 444.

8 J. Niederöst, Das Relief der Urschweiz von Franz Ludwig Pfyffer (1716-1802): 3D-Rekonstruktion, Analyse und Interpretation, Diss. Ing. ETH, Zürich 2005. Autorka w ramach swojej dysertacji z dziedziny geodezji pomierzyła „Relief Praszwajcarii” i porównała uzyskane wartości z aktualnymi danymi topograficznymi regionu. 


\section{Ogląd}

Relief był jedną z największych atrakcji Szwajcarii w późnym XVIII wieku. Z całej Europy do Lucerny przybywali naukowcy, artyści i pisarze, aby obejrzeć dzieło Pfyffera. W ramach wspomnianego projektu badawczego w 150 relacjach z podróży bądź publikacjach naukowych z tamtych czasów odnaleziono opisy tegoż reliefu, należy jednak zakładać, że takich deskrypcji jest o wiele więcej.

Takie spojrzenie umożliwiało całkowitą zmianę perspektywy. Nagle można było spojrzeć z góry na krajobraz, który do tej pory widziało się tylko z dołu, względnie, który zamykał widok ze wszystkich stron. W tym samym czasie, kiedy Pfyffer wykańczał swój relief, bracia Montgolfier unieśli się pierwszym balonem, również umożliwiając tę zmianę perspektywy.

Jednak nie traktujcie tego dzieła sztuki jako czegoś, co służy jedynie przepędzeniu wolnego czasu i uciesze miłośnika takiej rozrywki; raczej jako dzieło rzucające na historię naturalną Szwajcarii więcej światła niż wszystkie podróże, które można przedsięwziąć; kiedy to zawsze ma się przed sobą góry zasłaniające dal i relacje w terenie. Mając natomiast tutaj całość, którą można oglądać jakby z lotu ptaka, pojmujemy niepomiernie wyraźniej stworzenie naszej kuli ziemskiej i wszystkie przypadki, które w nim uczestniczyły

— pisał w 1778 roku berneński badacz Alp Gottlieb Sigmund Gruner ${ }^{9}$, po tym jak szczegółowo przestudiował relief Pfyffera.

Jakież to informacje dotyczące historii naturalnej można więc było wyczytać z reliefu, abstrahując od przekazywanej przez niego wiedzy o topografii?

\section{Lasy, śnieg i lód, struktura skał}

„Zaznaczam formę domów, każdy mały strumień, zarośla, skały, łąki i pola, wąwozy. Rozróżniam lasy dębowe, bukowe i iglaste [...]. Przyzna Pan, mój Panie, że oznacza to dużo pracy"10 _ pisał Pfyffer w 1769 roku do genewskiego inżyniera i geodety Jacques'a-Barthélemy Micheli du Cresta, który znany był dzięki pierwszej stworzonej przez niego w roku 1754 panoramie Alp ${ }^{11}$. W istocie wielu oglądających relief podkreślało, jak dokładnie widać na nim roślinność górską, w szczególności przemianę położonych niżej lasów liściastych w lasy iglaste

${ }^{9}$ G.S. Gruner, Reisen durch die merkwürdigsten Gegenden Helvetiens, t. 2, London 1778, s. 66 .

10 Pfyffer do Micheliego, 28 kwietnia 1761, Archives d'Etat de Genève, Arch. Micheli, Papiers JBMC, $\mathrm{n}^{\circ} 720 \mathrm{bis}$.

11 Por. M. Rickenbacher, Das Alpenpanorama von Micheli du Crest - Frucht eines Versuches zur Vermessung der Schweiz im Jahre 1754, „Cartographica Helvetica” 8, 1995, s. 1-23. 
wyższych partii aż po ich granicę konstatowano z dużym zainteresowaniem, nie posiadano bowiem podówczas danych dotyczących tych zjawisk ${ }^{12}$.

Dziś już nie widać tego na reliefie. Badania w 2000 roku wykazały, że pokrywają go 23 warstwy pokostu, zamalowań, zabrudzeń, środków czyszczących, zeszlifowań, nowych zamalowań, w tym farbami, o których wiadomo, że zostały wynalezione dopiero w XIX wieku ${ }^{13}$. Ale istnieje jeszcze inne źródło, a mianowicie rysunki terenowe Pfyffera. Zachowało się $91 \mathrm{z}$ nich, lecz z pewnością to tylko ułamek. Pfyffer szkicował je na miejscu ołówkiem, a potem kolorował w domu, posługując się kluczem barw, za pomocą którego zaznaczał określone cechy krajobrazu.

Jak bardzo interesowała go struktura rozległych lasów, ukazuje widok Rigi z Lauerz (zob. ilustracja 2). Las na jednej z flank góry, tak zwanej Hochflue, jest utrzymany raczej w tonacji ciemnej zieleni, co wskazuje na dominację lasów iglastych, podczas gdy jaśniejsza kolorystyka oznacza leżące pomiędzy nimi powierzchnie pokryte trawą i gajami. W XVIII wieku nie dysponowano systematyczną wiedzą o granicy lasu, która została zaznaczona na reliefie, podobnie było z granicą śniegu. Pfyffer chciał dać odpowiedź i na to pytanie. Granicę tę wyznaczył mniej więcej na wysokości 2300 metrów. Została ona na reliefie oznaczona kolorem. Słynny przyrodnik z Genewy Horace-Bénédict de Saussure odniósł się do tego wyraźnie w czwartym tomie swojego Voyage dans les Alpes (1780), przejmując dane Pfyffera, gdyż zdaniem de Saussure'a zbadał on tę kwestię najdokładniej i dał odpowiedź prawdziwszą niż na przykład berneńscy badacze Alp ${ }^{14}$.

Kolejne pytanie stawiane w tamtej epoce dotyczyło budowy Alp. Przed każdym odwiedzającym, który tylko chciał tego słuchać, Pfyffer roztaczał więc swoją teorię, którą William Coxe oddał następująco:

Generał przekazał mi dziwną informację, że szczyty Alp przecinające Szwajcarię w tworzonej linii są niemal równej wysokości; lub mówiąc wyraźniej, że tworzą nieprzerwane łańcuchy gór tej samej wysokości, które krok po kroku razem wznoszą się aż do najwyższego szeregu, a potem w tym samym stosunku opadają krok po kroku w stronę Włoch ${ }^{15}$.

Wznoszenie i opadanie było czterostopniowe na północy i na południu, Pfyffer tłumaczył je ,tak jak Saussure — wypłukiwaniem przez wodę"16. Pfyffer należał więc do neptunistów.

12 Por. A. Bürgi, Waldforschung beim Kartografieren. Bäume und Wald auf Franz Ludwig Pfyffers ,,Relief der Urschweiz“, [w:] Baumschule. Kultivierung des Stadtdschungels, red. D. Ghiggi, Baden 2010, s. 51-60.

13 Sprawozdanie Szwajcarskiego Instytutu Wiedzy o Sztuce: Schweizerisches Institut für Kunstwissenschaft: Untersuchungsbericht vom 30.09.1998, Kontroll-Nummer 29'139, Franz Ludwig Pfyffer: „Relief der Urschweiz “, Gletschergarten Luzern.

14 H.B. de Saussure, Reisen durch die Alpen, Leipzig 1788, t. 4, s. 125.

$15 \mathrm{~W}$. Coxe, Briefe über den natürlichen, bürgerlichen und politischen Zustand der Schweiz, t. 1, Zürich 1787 , s. 85.

${ }^{16}$ L. Meister, Kleine Reisen durch einige Schweizer Cantone, Basel 1782, s. 66. 
Dzięki „Reliefowi Praszwajcarii” można było po raz pierwszy ujrzeć znaczący wycinek przestrzeni Alp jako jedność i prześledzić wszystkie występujące w niej zależności topograficzne, ale i budowę: od jezior i nizin po alpejskie łąki, przez skały oraz złomiska aż do lodowców i pól firnu na górze. Takie przedstawienie przestrzeni alpejskiej było czymś nowym.

\section{Adolf Traugott von Gersdorf (1744-1807)}

W kontekście konferencji odbywającej się w Polanicy-Zdroju, w bezpośrednim sąsiedztwie saksońskich Łużyc, trzeba wspomnieć podróżnika, który zasłużył się geologicznymi badaniami Karkonoszy, lecz pozostawił także tysiącstronicowy dziennik swej podróży alpejskiej - Adolfa Traugotta von Gersdorfa, przyrodnika i współzałożyciela w 1779 roku Górnołużyckiego Towarzystwa Wiedzy w Zgorzelcu. Wraz z żoną i przyjacielem przedsięwziął latem 1786 roku podróż do Szwajcarii, której nadrzędnym celem było zebranie wiedzy o topografii i budowie Alp. Był więc mineralogicznym podróżnikiem, jakby go nazwano w terminologii tamtych czasów.

Także dla Gersdorfa reliefy były istotnym elementem badań nad geologią Alp. Naturalnie Lucerna ze względu na relief Pfyffera od początku została zaplanowana jako stacja w podróży. Gersdorf obejrzał model wielokrotnie, niestety pod nieobecność Pfyffera, czego żałował, gdyż musiał obyć się bez objaśnień, na które liczył. Na podstawie tegoż reliefu poprawił swoje notatki dotyczące topografii, odnotował jednak również zauważone na reliefie błędy. Słusznie stwierdził, że figury gór jeszcze nie całkiem odpowiadały naturze, gdyż jak już wspomniano, były one na reliefie przedstawione jako wyższe niż w rzeczywistości. „Tymczasem model ten jest z pewnością najpoprawniejszym z dzieł swego rodzaju"17 - uznał.

W czasie swej podróży Gersdorf zakupił trzy reliefy Charles'a François Exchaqueta (1746-1792), będącego dyrektorem towarzystwa górniczego w Wallis, a oprócz tej działalności dokonującego pomiarów okolicy między Pays de Vaud i Chamonix. Na podstawie uzyskanych wyników rozpoczął w 1787 roku sporządzanie rzeźbionych w drzewie reliefów Gotthard i Mont Blanc, które były bardzo poszukiwane. Gersdorf kupił od niego trzy reliefy przedstawiające Gotthard, Mont Blanc oraz dolinę Chamonix (zob. ilustracja 3), a także tak zwany kieszonkowy relief krainy Waadtland. Określano tak małe reliefy, które sporządzane w kieszonkowym formacie $10 \times 15 \mathrm{~cm}$ nadawały się do zabrania w podróż. Dodatkowo do reliefów Gotthard i Mont Blanc dał sobie przygotować przez lozańskiego chemika i mineraloga Henriego Struve (1751-1826) zestaw 75 bądź 94 próbek skalnych dokumentujących budowę geologiczną tych gór. Była to typowa procedura zastosowania reliefów w procesie badań naukowych: za pomocą modeli terenu

17 Adolf Traugott von Gersdorf: Bemerkungen auf einer Reise durch die Schweiz in Gesellschaft meiner Frau und des Herrn von Meyers im Sommer 1786, s. 290, https://gersdorf.collegium. ethz.ch/ (dostęp: 30.04.2020).

Góry - Literatura - Kultura 14, 2020

(C) for this edition by CNS 
uzyskiwano ogląd, dostarczały one widoku z lotu ptaka, a to z kolei umożliwiało przyporządkowanie szczegółów, w tym przypadku próbek skalnych. Nie inaczej postępowano w kwestiach dotyczących wegetacji, granicy śniegu i lodowców. Lubiano też zawieszać wokół reliefu widoki odpowiednich krajobrazów, ukazując w ten sposób ich topografię i geografię. Jest to udowodnione, jeśli chodzi o Pfyffera ${ }^{18}$. Znajdował się wreszcie w Szwajcarii relief, który posłużył do rozstrzygania za pomocą takich konkretnych ,próbek” nawet kwestii antropologicznych, między innymi tego, jaki krajobraz wytwarza jaki typ człowieka.

Od 1785 roku argowijski fabrykant jedwabiu Johann Rudolf Meyer (17391813) zlecał Johannowi Heinrichowi Weissowi (1758-1826) - ingénieur géographe z Alzacji — oraz Joachimowi Eugenowi Müllerowi (1752-1833) — topografowi i uznanemu budowniczemu reliefów - topograficzne ujęcie terenu Alp Szwajcarskich i Przedgórza pomiędzy Jeziorem Genewskim a Jeziorem Bodeńskim oraz wykonanie reliefu wielkości 4,40 $\times 1,95$ metra $^{19}$. Relief ten był gotowy około 1790 roku. Dziś już nie istnieje. Jednocześnie Meyer zlecił malarzowi z Lucerny Josephowi Reinhardowi (1749-1824) sportretowanie typowych reprezentantów różnych regionów Szwajcarii. W ten sposób powstało 140 obrazów typów ludu szwajcarskiego, które Meyer rozwiesił w swoim argowijskim domu wokół reliefu i w ten sposób — tak jak zrobił to Gersdorf ze swymi próbkami skalnymi - zebrał wokół reliefu, można powiedzieć, próby ludzkie dokumentujące skład społeczeństwa szwajcarskiego. Obrazy te nie miały ambicji artystycznych, raczej naukowe, co widać między innymi w proporcjach ciała do o wiele za dużej głowy, wyrażających ówczesne zainteresowanie fizjonomiką (zob. ilustracja 4).

W ważnym momencie historii poznania Alp reliefy pomogły odpowiedzieć na otwarte naukowe pytania. Nowy ogląd, obraz z lotu ptaka, umożliwiał orientację przestrzenną w terenie, dostarczały też o nim informacji, przede wszystkim o przyrodniczych zależnościach, czego nie mogły zaoferować mapy z tamtych czasów. W tym sensie reliefy z późnego XVIII wieku należy postrzegać jako dzieła prekursorskie wobec ikonicznego przedstawienia przekroju Ameryki Południowej Alexandra von Humboldta, na którym po raz pierwszy próbowano synoptycznie ukazać zależności przyrody ${ }^{20}$. Jednak dopiero w XIX wieku możliwe stało się — dzięki kolorowemu drukowi, poziomicom oraz jednolitemu północno-zachodniemu oświetleniu — umieszczenie na mapach wszystkich tych informacji, które wcześniej oferował relief. W swej poglądowości jednak reliefy nie mają sobie równych. Dlatego rozpowszechnione są również w epoce digitalnej, zarówno w formie elektronicznej, jak i namacalnie materialnej.

Z języka niemieckiego przełożyła Monika Witt

18 Por. Ch.G. Schmidt, Von der Schweiz. Journal meiner Reise 1786/1787, Bern-Stuttgart 1985, s. 63; H. von Pückler Muskau, Briefe aus der Schweiz, red. Ch. Linsmayer, Zürich 1981, s. 38.

19 M. Rickenbacher, Napoleons Karten der Schweiz. Landesvermessung als Machtfaktor 1798-1815, Baden 2011, s. 98. Skala wynosiła 1: 60000.

20 A. von Humboldt, Essai sur la géographie des plantes, Paris 1805.

Góry - Literatura - Kultura 14, 2020

(C) for this edition by CNS 